\title{
Conhecimento e autoconfiança de Agentes Comunitários de Saúde sobre Primeiros Socorros e Parada cardiopulmonar
}

\author{
Knowledge and Confidence among Community Health Workers on \\ First Aid and Cardiopulmonary Resuscitation
}

Conocimiento y grado de confianza de los agentes comunitarios de salud sobre primeros auxilios y reanimación cardiopulmonar

Como citar este artigo:

Martins, Débora Maria Bezerra; Brandão, Maria Girlane Sousa Albuquerque; Araújo, Francisca Drenalina de Sousa; Albano, Livia Maria Camelo; Ávila, Erilandy de Sousa; Neto, Nelson Miguel Galindo; Barros, Lívia Moreira. Conhecimento e autoconfiança de Agentes Comunitários de Saúde sobre Primeiros Socorros e Parada cardiopulmonar. Revista Cuidarte. 2021;12(2):e1162. http://dx.doi.org/10.15649/cuidarte.1162

Revista Cuidarte

Rev Cuid. May - Ago 2021; 12(2): e1162

doil http://dx.doi.org/10.15649/cuidarte.1162

E-ISSN: 2346-3414

(1) Débora Maria Bezerra Martins ${ }^{1}$

(1) Maria Girlane Sousa Albuquerque Brandão ${ }^{2}$

(1) Francisca Drenalina de Sousa Araújo 3

(1) Livia Maria Camelo Albano ${ }^{4}$

(1) Erilandy de Sousa Ávila ${ }^{5}$

(1) Nelson Miguel Galindo Neto ${ }^{6}$

(1) Lívia Moreira Barros

1 Enfermeira pela Universidade Estadual Vale do Acaraú (UVA). Sobral, Ceará, Brasil. E-mail: deboramaria2048@gmail.com

2 Enfermeira pela Universidade Estadual Vale do Acaraú (UVA). Mestre em Enfermagem pela Universidade da Integração Internacional da Lusofonia Afro-Brasileira (UNILAB). Doutoranda em Enfermagem Fundamental pela Universidade de São Paulo (USP). Ribeirão Preto, São Paulo, Brasil. E-mail: girlanealbuquerque@usp.br

3 Enfermeira pela Universidade Estadual Vale do Acaraú (UVA). Enfermeira assistencialista na Santa Casa de Misericórdia de Sobral. Sobral, Ceará, Brasil. E-mail: drenalina@live.com

4 Enfermeira pela Universidade Estadual Vale do Acaraú (UVA). Sobral, Ceará, Brasil. E-mail: liviaalbano22@gmail.com

5 Enfermeira pela Universidade Estadual Vale do Acaraú (UVA). Residente em Urgência e Emergência. Sobral, Ceará, Brasil. E-mail: erilandyavila@gmail.com

6 Doutor em Enfermagem. Instituto Federal de Educação, Ciência e Tecnologia de Pernambuco, Caruaru, PE, Brasil. E-mail: nelsongalindont@hotmail.com

7 Doutora em Enfermagem. Universidade da Integração Internacional da Lusofonia Afro-Brasileira (UNILAB). Redenção, Ceará, Brasil. E-mail: livia.moreirab@hotmail.com

\section{Resumo}

Introdução: Os Agentes Comunitários de Saúde são uma categoria profissional no Brasil que se encontram contato direto e diário com os usuários na comunidade e possuem maior probabilidade de se deparar com situações de emergência ou primeiros socorros. Objetivo: Avaliar o conhecimento e autoconfiança de Agentes Comunitários de Saúde sobre Primeiros Socorros e Parada cardiopulmonar. Materiais e Método: Estudo descritivo e quantitativo, realizado de junho a outubro de 2018, em 22 Centros de Saúde da Família de município do Ceará, Brasil, com 186 Agentes Comunitários de Saúde, divididos em dois grupos: aqueles já tinham treinamento sobre a temática e os que não possuíam treinamento. Na coleta de dados foi aplicado questionário com: 1) caracterização da amostra; 2) Questões sobre Parada Cardiopulmonar; 3) Questões sobre primeiros socorros; 4) Escala de autoconfiança. Resultados: Houve diferença significante entre os grupos nas questões de conhecimento em quatro itens, nas questões sobre definição de PCR, verificação da responsividade de uma vítima desacordada, sequência para o posicionamento das mãos e braços na ressuscitação cardiopulmonar (RCP) e momento de troca dos socorristas. Nos primeiros socorros, houve diferença estatisticamente significante em quatro itens, nas questões de primeira conduta no caso de precisar atender uma vítima em situação de urgência, cuidados durante uma crise de convulsão, condutas com vítimas de afogamento e cuidados com bebê engasgado. Ambos os grupos apresentaram autoconfiança baixa para intervir em situações de emergências cardíacas, neurológicas e respiratórias. Conclusão: Os achados da pesquisa apontam déficit de conhecimento dos agentes comunitários de saúde para atuar frente a parada Cardiopulmonar e em situações de primeiros socorros, associado à baixa autoconfiança para intervir em situações de emergências.

Palavras-Chave: agentes comunitários de saúde; conhecimento; parada cardíaca, ressuscitação cardiopulmonar.
Recebido: março 21 de 2020

Aceito: fevreiro 2 de 2021

Publicado: abril 30 de 2021 $\square *$ Correspondencia

Maria Girlane Sousa Albuquerque Brandão

E-mail: girlanealbuquerque@usp.br 


\title{
Knowledge and Confidence among Community Health Workers on First Aid and Cardiopulmonary Resuscitation
}

\begin{abstract}
Introduction: Community health workers are considered a professional health category in Brazil who are in direct daily contact with community users and, therefore, more likely to face emergency or first aid situations. Objective: To assess the level of knowledge and confidence of community health workers on first aid and cardiopulmonary resuscitation. Materials and Methods: A descriptive quantitative study was conducted between June and October 2018 in 22 Family Health Centers in a city in Ceará, Brazil with 186 community agents grouped as follows: a group that has already received training on these matters and another group that has not had such training. For data collection, a questionnaire containing the following items was administered: 1) sample characterization; 2) questions on cardiopulmonary resuscitation; 4) questions on first aid; 4) confidence scale. Results: A significant difference among both groups was found in questions related to the knowledge of the four items, especially for explaining CPR, checking for responsiveness of an unconscious person, the sequence for placing hands and arms in cardiopulmonary resuscitation (CPR) and rotating resuscitators. Regarding first aid, a statistically significant difference was also found in four items related to first aid questions when attending a victim in an emergency such as convulsions, drowning and choking in children. Both groups showed low confidence to intervene in cardiac, neurological and respiratory emergencies. Conclusions: Research results indicate that there is a lack of knowledge among community health workers to respond effectively to situations involving cardiopulmonary resuscitation and first aid, which is also associated with low confidence to perform interventions in emergencies.
\end{abstract}

Keywords: community health workers; knowledge; heart arrest; cardiopulmonary resuscitation.

\section{Conocimiento y grado de confianza de los agentes comunitarios de salud sobre primeros auxilios y reanimación cardiopulmonar}

\section{Resumen}

Introducción: Los agentes comunitarios de salud constituyen una categoría sanitaria profesional en Brasil que está en contacto directo a diario con los usuarios de la comunidad, por lo que tiene más probabilidades de enfrentarse a situaciones de emergencia o primeros auxilios. Objetivo: Evaluar los conocimientos y el grado de confianza de los agentes comunitarios de salud en materia de primeros auxilios y reanimación cardiopulmonar. Materiales y Métodos: Se realizó un estudio cuantitativo descriptivo entre junio y octubre de 2018 en 22 Centros de Salud Familiar de una ciudad del estado de Ceará, Brasil con 186 agentes comunitarios, que luego fueron agrupados así: un grupo que ya contaba con formación sobre estos temas y otro grupo que no contaba con dicha formación. Para la recolección de datos, se administró un cuestionario que contenía los siguientes ítems: 1) caracterización de la muestra; 2) preguntas sobre reanimación cardiopulmonar; 3) preguntas sobre primeros auxilios; 4) escala del grado de confianza. Resultados: Se presentó una diferencia significativa entre los grupos en cuanto a las preguntas relacionadas con los conocimientos de los cuatro ítems, especialmente en cuanto a la definición de RCP, la comprobación de la capacidad de respuesta de una víctima en estado de inconciencia, la secuencia para la colocación de manos y brazos en la reanimación cardiopulmonar (RCP) y los turnos para cambiar los reanimadores. En cuanto a primeros auxilios, también se presentó una diferencia estadísticamente significativa en cuatro ítems relacionados con preguntas de primeros auxilios en caso de necesitar atender una víctima en una situación de emergencia, durante una crisis convulsiva o víctimas de ahogamiento y atragantamiento en bebés. Ambos grupos presentaron un bajo grado de confianza para realizar intervenciones en situaciones de emergencias cardíacas, neurológicas y respiratorias. Conclusiones: Los resultados de la investigación apuntan a un déficit de conocimiento por parte de los agentes comunitarios de salud para actuar frente situaciones que requieren reanimación cardiopulmonar y primeros auxilios, lo cual está también asociado a un bajo grado de confianza para realizar intervenciones en situaciones de emergencia.

Palabras clave: agentes comunitarios de salud; conocimiento; paro cardíaco; reanimación cardiopulmonar. 


\section{Introdução}

Os Agentes Comunitários de Saúde (ACS) são uma categoria profissional no Brasil, que representamo elo entre comunidade e Estratégia Saúde da Família (ESF), e estão contextualizados no histórico da saúde brasileira. Os ACS foram instituídos no Sistema Único de Saúde (SUS) no ano de 1991, por meio do Programa de Agentes Comunitários de Saúde (PACS) e têm contribuído para a extensão de cobertura e a estruturação da Atenção Primária à Saúde (APS) no País, pois estão presentes em $98 \%$ dos municípios brasileiros' ${ }^{1}$.

Estima-se que, em 2018, havia 263.756 ACS em exercício'. Dentro da ESF, a visita domiciliar é uma das principais atividades da rotina de trabalho do ACS, o qual se encontra em contato direto e diário com os usuários na comunidade².

Por atuar diretamente na comunidade e no domicílio, os ACS são os profissionais de saúde que têm maior probabilidade de presenciar e ter que intervir em uma situação de emergência ou primeiros socorros.

No Brasil, acidentes em domicílio e espaço escolar Por atuar diretamente na
comunidade e no domicílio,
os ACS são os profissionais
de saúde que têm maior
probabilidade de presenciar e
ter que intervir em uma situação
de emergência ou primeiros
socorros. são a maior causa de morte entre crianças de 1 a 14 anos $^{3}$, onde os primeiros socorros são fundamentais. São registrados anualmente cerca de 100 mil casos de Parada Cardiopulmonar (PCR) no ambiente extra-hospitalar, em que quatro de cinco PCR acontecem no ambiente domiciliar ${ }^{3}$. Isso ressalta a relevância do ACS estar apto para reconhecer e intervir adequadamente em situação de emergência ou primeiros socorros ${ }^{4}$.

Contudo, estudos consultados apontam que os ACS apresentam dificuldades para atuar em situações de primeiros socorros/suporte básico de vida, com demonstração de incertezas sobre manobras de ressuscitação cardiopulmonar (RCP), primeiros socorros e intervenção inadequada diante das vítimas ${ }^{5,6}$.

Os ACS são componentes da ESF que permanecem grande parte do dia com os clientes em domicílio e a qualquer momento, poderão se deparar com eventos que necessitam de reconhecimento e abordagem rápida. Desse modo, é pertinente analisar o conhecimento desses profissionais em casos de emergências, como a PCR e outras situações de primeiros socorros.

\begin{abstract}
Os ACS são componentes da ESF que permanecem grande parte do dia com os clientes em domicílio e a qualquer momento, poderão se deparar com eventos que necessitam de reconhecimento e abordagem rápida.
\end{abstract}

Cabe a essa categoria leiga tomar posse desse saber (primeiros socorros), como também serem instruídos por meio de capacitações que fortaleçam o conhecimento e a prática. Diante desse fato, surgiu a seguinte indagação: os ACS possuem conhecimento adequado sobre cuidados relacionados aos primeiros socorros?

Os resultados deste estudo poderão gerar evidências que apontem o nível de conhecimento e autoconfiança desses profissionais para proporcionar atendimento eficaz e elevar taxas de sobrevida em casos de agravos clínicos cardiopulmonar e primeiros socorros, e assim, demonstrar a necessidade de capacitação constante dessa categoria profissional.

O estudo tem o objetivo de avaliar o conhecimento e autoconfiança de Agentes Comunitários de Saúde sobre Primeiros Socorros e Parada cardiopulmonar. 


\section{Materiais e métodos}

Estudo descritivo com abordagem quantitativa, realizado no período de junho a outubro de 2018, em 22 Centros de Saúde da Família (CSF) de município do estado do Ceará, Nordeste Brasil, que possui abrangência de cobertura assistencial de 100\% da população.

A população-alvo foi representada por 292 ACS que compõem a equipe da ESF da sede do município. Para amostra do estudo, foi utilizada amostragem do tipo não probabilística intencional. A amostra foi calculada a partir da fórmula para população finita, que totalizou uma amostra final de 166 participantes. Dos 292 ACS, 186 aceitaram participar do estudo e, assim, compuseram a amostra. Os participantes do presente estudo foram divididos em dois grupos: os que já haviam realizado algum treinamento previamente e os que não realizaram.

Os critérios de inclusão foram: ACS inseridos na sede do município e que possuíam acima de três meses de atuação no serviço. Como critérios de exclusão: ACS em serviços administrativos; ACS afastados por férias ou de licença saúde e que possuíssem curso técnico ou de graduação relacionado à área da saúde. Após aplicação dos critérios, foi excluído um participante da amostra devido o mesmo ser discente de enfermagem.

Na coleta de dados foi aplicado questionário com variáveis organizadas em quatro partes: 1) caracterização sociodemográfica e profissional da amostra (sexo, idade, estado civil, renda e tempo de trabalho); 2) Questões objetivas sobre PCR conforme as diretrizes da American Heart Association $(\mathrm{AHA})^{7}$ com quatro opções de resposta; 3) Questões objetivas sobre primeiros socorros (abordagem inicial, vertigens e desmaios, epistaxe, asfixia, hemorragia, ferimento, fraturas, queimaduras e convulsão) com quatro opções de resposta; 4) Escala de autoconfiança para intervenção em situações de emergências cardíacas, respiratórias e neurológicas ${ }^{8} \mathrm{com}$ cinco opções de resposta.

A escala de autoconfiança para intervenção em emergências possui 12 itens de respostas tipo likert de 5 pontos, onde 1 representa nada confiante; 2 pouco confiante; 3 confiante; 4 muito confiante e 5 extremamente confiante. Foi considerado autoconfiança baixa as médias de 1,0 a 2,99, autoconfiança moderada as de 3 a 3,99 e alta autoconfiança pontuações de 4,0 a 5,0 ${ }^{8}$.

Os dados foram tabulados no Excel 2016 e analisados no programa estatístico Statistical Package for the Social Sciences (SPSS) versão 25 para obtenção de frequências absolutas e percentuais, médias e desvio-padrão, além de testes estatísticos de acordo com as variáveis do instrumento. Utilizou-se o Teste de Mann-Whitney para amostras independentes e Qui-Quadrado de Pearson nas comparações das variáveis categóricas. O nível de significância adotado foi $5 \%$ com intervalo de confiança de $95 \%$.

A pesquisa foi aprovada pelo Núcleo de Estudos e Pesquisas em Saúde (NEPS) do município pesquisado, por meio do parecer n 0005/2018 e pelo Comitê de Ética e Pesquisa da Universidade Estadual Vale do Acaraú sob parecer de n $2.649 .144 / 2018$, seguiu as consignações da Resolução n. ${ }^{\circ} 466 / 12$, do Conselho Nacional de Saúde, e todos os participantes assinaram o Termo de Consentimento Livre e Esclarecido. 


\section{Resultados}

Os resultados obtidos no presente estudo foram divididos em dois grupos, os que já haviam realizado algum treinamento previamente e os que não realizaram. Dentre os 186 participantes, 80 tinham participado de treinamentos sobre a temática pesquisada e 106 não realizaram nenhum treinamento.

No grupo que havia participado de treinamento, $86,3 \%$ (69) dos participantes eram do sexo feminino, com idade média de 39,3 anos e tempo média de atuação de 12,3 anos. O grupo sem treinamento constava de $84 \%$ (89) mulheres, com idade média de 36,7 anos e tempo de atuação de 8,2 anos, observados na Tabela 1.

Tabela 1 - Caracterização da amostra, Sobral, Ceará, Brasil - 2018.

\begin{tabular}{|c|c|c|c|c|c|}
\hline \multirow{3}{*}{ Variáveis /Categorias } & \multicolumn{4}{|c|}{ Grupo } & \multirow{3}{*}{ P-valor } \\
\hline & \multicolumn{2}{|c|}{$\begin{array}{l}\text { Realizou treinamento } \\
\text { (80) }\end{array}$} & \multicolumn{2}{|c|}{$\begin{array}{l}\text { Não realizou treinamento } \\
(106)\end{array}$} & \\
\hline & $\mathbf{n}$ & $\%$ & $\mathbf{n}$ & $\%$ & \\
\hline Sexo & & & & & 0,666 \\
\hline Feminino & 69 & 86,3 & 89 & 84,0 & \\
\hline Masculino & 11 & 13,8 & 17 & 16,0 & \\
\hline Idade Média (DP) & \multicolumn{2}{|c|}{$39,38(9,192)$} & \multicolumn{2}{|c|}{$36,73(10,481)$} & $0,045^{*}$ \\
\hline Tempo de atuação Média (DP) & \multicolumn{2}{|c|}{$12,38(8,109)$} & \multicolumn{2}{|c|}{$8,21(8,543)$} & $0,001 *$ \\
\hline
\end{tabular}

No que se refere ao conhecimento dos ACS, houve diferença estatisticamente significante entre os grupos nas questões sobre definição de $\mathrm{PCR}$, verificação da responsividade de uma vítima desacordada, sequência para o posicionamento das mãos e braços na ressuscitação cardiopulmonar (RCP) e momento de troca dos socorristas.

Houve proporção de acertos maior que $70 \%$ em apenas três itens, referentes ao número para solicitar o Serviço de Atendimento Móvel de Urgência (SAMU), posição que deve colocar a vítima para realizar compressão no tórax e onde posicionar as mãos para fazer a compressão.

Os itens nos quais os acertos se exibiram mais baixos foram sobre os cuidados a serem tomados na utilização do Desfibrilador Externo Automático (DEA), quantidade de compressões por minuto e proporção de compressões torácicas e respirações (Tabela 2).

Na tabela 3, é possível observar as questões sobre os cuidados em situações de primeiros socorros. Houve diferença estatisticamente significante entre os grupos nas questões de primeira conduta no caso de precisar atender uma vítima em situação de urgência, cuidados durante uma crise de convulsão, condutas com vítimas de afogamento e cuidados com bebê engasgado.

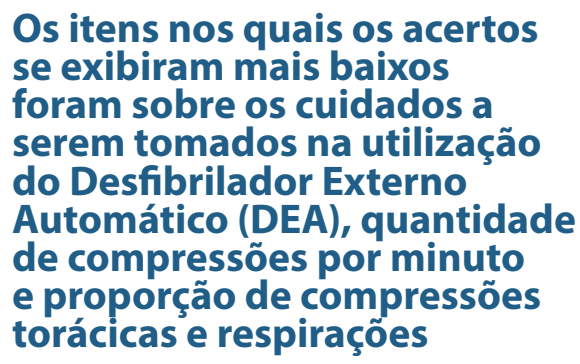

Os itens nos quais os acertos sexibiram mais baixos serem tomados na utilização do Desfibrilador Externo Automático (DEA), quantidade e proporção de compressões torácicas e respiraçōes 
Tabela 2 - Distribuição do conhecimento dos Agentes Comunitários de Saúde PCR. Sobral, Ceará, Brasil - 2018.

\begin{tabular}{|c|c|c|c|}
\hline \multirow{3}{*}{ Itens de avalição do conhecimento sobre PCR } & \multicolumn{2}{|c|}{ ACERTOS } & \multirow{3}{*}{ p-valor } \\
\hline & \multirow{2}{*}{$\begin{array}{c}\begin{array}{c}\text { Com } \\
\text { treinamento }\end{array} \\
\mathrm{N}(\%) \\
\end{array}$} & \multirow{2}{*}{$\begin{array}{c}\begin{array}{c}\text { Sem } \\
\text { treinamento }\end{array} \\
\mathbf{N}(\%) \\
\end{array}$} & \\
\hline & & & \\
\hline 1. Definição de parada cardiorrespiratória (PCR) & $31(38,8)$ & $22(20,8)$ & 0,007 \\
\hline 2. Verificação da responsividade de uma vítima desacordada & $37(46,3)$ & $21(19,8)$ & 0,000 \\
\hline 3. Local para verificar a pulsação da vítima & $47(58,8)$ & $48(45,3)$ & 0,069 \\
\hline 4. Momento de iniciar as compressões em uma PCR & $26(32,5)$ & $31(29,2)$ & 0,634 \\
\hline 5. Número para solicitar o SAMU & $72(90,0)$ & $90(84,9)$ & 0,305 \\
\hline 6. O que fazer se for detectado irresponsividade & $29(36,3)$ & $30(28,3)$ & 0,249 \\
\hline 7. Cuidados a serem tomados na utilização do DEA & $07(8,8)$ & $14(13,2)$ & 0,342 \\
\hline 8. Sequência para o posicionamento das mãos e braços na RCP & $26(32,5)$ & $14(13,2)$ & 0,002 \\
\hline $\begin{array}{l}\text { 9. Posição que deve colocar a vítima para realizar compressão } \\
\text { no tórax }\end{array}$ & $58(72,5)$ & $77(72,6)$ & 0,983 \\
\hline 10. Quantidade de compressões por minuto & $12(15,0)$ & $10(9,4)$ & 0,245 \\
\hline 11. Proporção de compressões torácicas e respirações & $13(16,3)$ & $13(12,3)$ & 0,438 \\
\hline $\begin{array}{l}\text { 12. Em que momento a pessoa que está fazendo as compressões } \\
\text { no tórax deve trocar para que outra pessoa faça a compressão }\end{array}$ & $25(31,3)$ & $18(17,0)$ & 0,022 \\
\hline $\begin{array}{l}\text { 13. Força que deve ser aplicada na compressão no tórax de um } \\
\text { adolescente ou adulto }\end{array}$ & $16(20,0)$ & $21(19,8)$ & 0,975 \\
\hline 14.Quando parar de fazer compressões no tórax & $48(60,0)$ & $56(52,8)$ & 0,330 \\
\hline 15. Definição de DEA & $27(33,8)$ & $43(40,6)$ & 0,342 \\
\hline 16. Local onde colocar as pás & $32(40,0)$ & $31(29,2)$ & 0,125 \\
\hline 17. O que fazer quando ajuda chegar & $26(32,5)$ & $28(26,4)$ & 0,365 \\
\hline 18. Onde posicionar as mãos para fazer a compressão no tórax & $61(76,3)$ & $70(66,0)$ & 0,131 \\
\hline 19. Como se posicionar para fazer compressão no tórax & $39(48,8)$ & $40(37,7)$ & 0,123 \\
\hline
\end{tabular}

$\uparrow$ Qui - quadrado de Pearson. Fonte: Dados da Pesquisa.

Tabela 3- Distribuição do conhecimento geral dos ACS sobre Primeiros Socorros. Sobral, Ceará, Brasil - 2018.

\begin{tabular}{|c|c|c|c|}
\hline \multirow{3}{*}{$\begin{array}{l}\text { Itens de avaliçãodo conhecimento sobre } \\
\text { Primeiros Socorros }\end{array}$} & \multicolumn{2}{|c|}{ ACERTOS } & \multirow{3}{*}{ p-valor $\dagger$} \\
\hline & \multirow{2}{*}{$\begin{array}{c}\text { Realizou treinamento } \\
\text { N (\%) }\end{array}$} & \multirow{2}{*}{$\frac{\text { Sem treinamento }}{\mathbf{N}(\%)}$} & \\
\hline & & & \\
\hline $\begin{array}{l}\text { 1. Primeira conduta no caso de precisar atender } \\
\text { uma vítima em situação de urgência. }\end{array}$ & $23(28,8)$ & $12(11,3)$ & 0,003 \\
\hline $\begin{array}{l}\text { 2. Cuidados de primeiros socorros para } \\
\text { intoxicação }\end{array}$ & $43(53,8)$ & $57(53,8)$ & 0,997 \\
\hline 3. Cuidados em ferimento com hemorragia. & $52(65,0)$ & $57(53,8)$ & 0,124 \\
\hline 4. Cuidados em ferimento com objeto encravado. & $63(63)$ & $88(83,0)$ & 0,461 \\
\hline 5. Cuidados durante uma crise de convulsão. & $57(71,3)$ & $54(50,9)$ & 0,005 \\
\hline 6. Acide ntes com corte no ambiente de trabalho & $61(76,3)$ & $73(68,9)$ & 0,267 \\
\hline 7. Cuidados com febre alta & $24(30,0)$ & $21(19,8)$ & 0,108 \\
\hline 8. Cuidados em queimaduras. & $24(30,0)$ & $29(27,4)$ & 0,693 \\
\hline 9. Condutas com adulto vítima de engasgo. & $56(70,0)$ & $65(61,3)$ & 0,219 \\
\hline 10. Condutas com vítim as de afogamento & $43(53,8)$ & $38(35,8)$ & 0,015 \\
\hline 11. Cuidados em amputação traumática & $27(33,8)$ & $34(32,1)$ & 0,810 \\
\hline $\begin{array}{l}\text { 12. Cuidados nos casos de acidentes por animais } \\
\text { peçonhentos. }\end{array}$ & $06(7,5)$ & $05(4,7)$ & 0,426 \\
\hline 13. Cuidados em desmaios & $30(37,5)$ & $27(25,5)$ & 0,078 \\
\hline 14. Cuidados com bebê engasgado & $58(72,5)$ & $54(50,9)$ & 0,003 \\
\hline $\begin{array}{l}\text { 15. Cuidados diante de um usuário que apresenta } \\
\text { sangramento nasal. }\end{array}$ & $32(40,0)$ & $34(32,1)$ & 0,263 \\
\hline 16. Sinais de suspeita de lesões musculoesqueléticas. & $22(27,5)$ & $32(30,2)$ & 0,689 \\
\hline
\end{tabular}


$\mathrm{Na}$ tabela 4, apresenta-se as variáveis relacionadas à autoconfiança dos ACS para atuar em situação de emergência. Verificou-se que a média das respostas no grupo que realizou treinamento foi de $2,19( \pm 0,49)$, enquanto que no grupo sem treinamento foi de 1,99 $( \pm 0,51)$. Assim, ambos os grupos apresentaram autoconfiança baixa para intervir em situações de emergências cardíacas, neurológicas e respiratórias.

Tabela 4 - Distribuição da Autoconfiança dos ACS. Sobral, Ceará, Brasil - 2018.

\begin{tabular}{|c|c|c|c|}
\hline \multirow[t]{2}{*}{ Variáveis } & \multicolumn{2}{|c|}{ Média (DP) } & \multirow[t]{2}{*}{ p-valor } \\
\hline & $\begin{array}{c}\text { Com } \\
\text { tr einamento }\end{array}$ & $\begin{array}{c}\text { Sem } \\
\text { treinamento }\end{array}$ & \\
\hline \multicolumn{4}{|l|}{ Emergências Cardíacas } \\
\hline $\begin{array}{l}\text { 1. Autoconfiança em reconhecer sinais e sintomas de } \\
\text { evento cardíaco }\end{array}$ & $2,19(0,638)$ & $1,92(0,700)$ & 0,006 \\
\hline $\begin{array}{l}\text { 2. Autoconfiança em ser capaz de avaliar com } \\
\text { precisão um indivíduo com dor torácica }\end{array}$ & $2,13(0,603)$ & $1,92(0,664)$ & 0,015 \\
\hline $\begin{array}{l}\text { 3. Autoconfiança em ser capaz de intervir } \\
\text { apropriadamente num indivíduo com dor torácica }\end{array}$ & $1,94(0,752)$ & $1,77(0,606)$ & 0,139 \\
\hline $\begin{array}{l}\text { 4. Autoconfiança em ser capaz de avaliar a eficácia } \\
\text { das suas intervenções num indivíduo com dor } \\
\text { torácica }\end{array}$ & $2,00(0,595)$ & $1,77(0,590)$ & 0,008 \\
\hline \multicolumn{4}{|l|}{ Emergências Respiratórias } \\
\hline $\begin{array}{l}\text { 5. Autoconfiança em reconhecer sinais e sintomas de } \\
\text { evento respiratório }\end{array}$ & $2,55(0,745)$ & $2,16(0,745)$ & 0,000 \\
\hline $\begin{array}{l}\text { 6. Autoconfiança em ser capaz de avaliar com } \\
\text { precisão um indivíduo com dispneia }\end{array}$ & $2,54(0,779)$ & $2,17(0,833)$ & 0,001 \\
\hline $\begin{array}{l}\text { 7. Autoconfiança em ser capaz de intervir } \\
\text { apropriadamente num indivíduo com dispneia }\end{array}$ & $2,16(0,625)$ & $1,94(0,701)$ & 0,017 \\
\hline $\begin{array}{l}\text { 8. Autoconfiança em ser capaz de avaliar a eficácia } \\
\text { das suas intervenções num indivíduo com } \\
\text { dispneia }\end{array}$ & $2,13(0,644)$ & $1,90(0,689)$ & 0,013 \\
\hline \multicolumn{4}{|l|}{ Emergências Neurológicas } \\
\hline $\begin{array}{l}\text { 9. Autoconfiança em reconhecer sinais e sintomas de } \\
\text { evento neurológico }\end{array}$ & $2,16(0,719)$ & $1,92(0,745)$ & 0,014 \\
\hline $\begin{array}{l}\text { 10. Autoconfiança em ser capaz de avaliar com } \\
\text { precisão um indivíduo com alteração do estado } \\
\text { mental }\end{array}$ & $2,49(0,763)$ & $2,44(0,782)$ & 0,618 \\
\hline $\begin{array}{l}\text { 11. Autoconfiança em ser capaz de intervir } \\
\text { apropriadamente num indivíduo com alteração do } \\
\text { estado mental }\end{array}$ & $2,06(0,663)$ & $1,99(0,762)$ & 0,417 \\
\hline $\begin{array}{l}\text { 12. Autoconfiança em ser capaz de avaliar a eficácia } \\
\text { das suas intervenções num indivíduo com } \\
\text { alteração do estado mental }\end{array}$ & $1,98(0,675)$ & $1,99(0,762)$ & 0,904 \\
\hline
\end{tabular}

$\uparrow$ Teste de Mann Whitney para comparação entre os grupos.

Fonte: dados da pesquisa

As diferenças estatisticamente significantes entre os grupos estiveram presentes nas questões sobre autoconfiança em reconhecer sinais e sintomas de evento cardíaco, respiratório e neurológico; autoconfiança em ser capaz de avaliar com precisão um indivíduo com dor
Assim, ambos os grupos apresentaram autoconfiança baixa para intervir em situações de emergências cardíacas, neurológicas e respiratórias. 
torácica e dispneia; autoconfiança em ser capaz de intervir apropriadamente num indivíduo com dispneia; autoconfiança em ser capaz de avaliar a eficácia das suas intervenções num indivíduo com dor torácica e com dispneia (Tabela 4).

\section{Discussão}

As características da amostra estudada se assemelham a outro estudo nacional, especialmente quanto ao tempo de trabalho e idade ${ }^{5}$. A mulher, enquanto profissional de saúde, representa quantitativamente a maioria, considerada culturalmente como provedora de cuidados.

No estudo em tela, os resultados encontrados demonstraram déficit de conhecimento dos ACS para reconhecer e manejar uma vítima de $\mathrm{PCR}$, na atuação em situações primeiros socorros, além de apresentar baixa autoconfiança para intervir em situações de emergências cardíacas, respiratórias e neurológicas.

No que se refere à $\mathrm{PCR}$, os maiores déficits foram detectados nos itens relacionados aos cuidados a serem tomados na utilização do DEA, quantidade de compressões por minuto e proporção de compressões torácicas e respirações.

A ausência de conhecimentos caracteriza umas das maiores barreiras que impede o início dos primeiros socorros à vítima em PCR devido ao medo de errar. Portanto, treinar a população para prestar assistência

A ausência de conhecimentos caracteriza umas das maiores barreiras que impede o início dos primeiros socorros à vítima em PCR devido ao medo de errar. adequada e de qualidade está diretamente interligado com a possibilidade de evitar sequelas e minimizar as taxas de mortalidade por PCR.

Os ACS que possuíam treinamento prévio apresentaram mais acertos no tópico de PCR, ressaltando que a capacitação contribui com o nível de conhecimento. Estudo realizado com 89 ACS de Unidades Básicas de Saúde do Sudeste do Brasil identificou aumento no número médio de acertos em teste de conhecimento realizado imediatamente após treinamento de Suporte Básico de Vida9. O conhecimento possibilita o reconhecimento ágil da PCR. Acionar socorro especializado possibilita a prevenção de lesões tanto no miocárdio como no cérebro ${ }^{10}$.

Assim, é relevante que os ACS tenham habilidades para reconhecer uma PCR, acionar o socorro e efetuar manobras adequadas, sendo pertinente a instrução sobre as técnicas em primeiros socorros com a finalidade de prevenir e minimizar a ocorrência de óbitos ${ }^{11}$. O potencial de recuperação de vítimas de PCR está relacionado com a rapidez com que as situações de urgência/emergência são reconhecidas e adequadamente tratadas.

Ao questionar sobre a identificação de uma vítima irresponsiva, foi possível observar que ambos os grupos não apresentaram percentual satisfatório de acertos, o que indica que tais profissionais não sabem como agir ao encontrar uma pessoa inconsciente.

Estudo realizado com ACS de Unidades Básica de Saúde do Nordeste brasileiro identificou que os ACS não possuem conhecimento científico e habilidade para atuar diante de situações de urgência ${ }^{6}$. Pesquisa realizada com 10 ACS do Sul do Brasil relevou que apenas três tiveram a oportunidade de atuar em uma RCP, mesmo não tendo conhecimento sobre as compressões e os participantes do estudo relataram que acreditavam que as vítimas estavam em óbito por não conseguir detectar pulso e respiração ${ }^{5}$. Esse fato expressa ausência de conhecimento dos ACS diante de um dos sinais relevantes para verificar uma PCR. 
Em relação à quantidade de compressões por minuto ambos os grupos apresentam baixas frequências de acertos. Pesquisa realizada com 350 profissionais de saúde da Tanzânia identificou que apenas $21 \%$ realizaram corretamente as manobras de compressão torácicas ${ }^{12}$. Na Etiópia, estudo com 397 profissionais de saúde relevou déficit de habilidade em Suporte Básico de Vida ${ }^{13}$.

Isso avigora a necessidade de maior qualificação dos profissionais de saúde, principalmente dos ACS, uma vez que a maioria dos casos de PCR acontece em ambiente extra-hospitalar e este profissional encontra-se em maior contato com a comunidade. Vale ressaltar que quantidade de compressões por minuto é primordial para RCP efetiva.
Isso avigora a necessidade de maior qualificação dos profissionais de saúde, principalmente dos ACS, uma vez que a maioria dos casos de PCR acontece em ambiente extra-hospitalar e este profissional encontra- se em maior contato com a comunidade.

No que se refere à relação entre compressões e ventilações ambos os grupos de ACS apresentaram 13\% de acertos. Pesquisa realizada com 129 profissionais de Unidades Básica de Saúde no Sudeste do Brasil identificou que 60,5\% responderam corretamente que, a cada 30 compressões, devem ser realizadas duas ventilações ${ }^{14}$. O foco da RCP eficaz está na capacidade do socorrista realizar compressões torácicas de qualidade intercalas com as respirações de emergência.

Para realizar as compressões torácicas de forma eficaz, exige-se frequência de 100 a 120 compressões por minuto (em vítima adulta) ${ }^{15}$, o que possibilita aumento da sobrevida já que frequências elevadas estão associadas com baixa diminuição da profundidade do tórax ${ }^{16}$.

Verificou-se ainda que os ACS de ambos os grupos não conheciam o DEA, sua função e local de aplicação das pás. O acesso rápido ao desfibrilador é componente essencial do sistema de atendimento, visto que há indícios nítidos de maior sobrevivência a PCR com o uso do DEA, quando necessário. Pesquisa efetivada com 185 profissionais da atenção primária de Israel identificou que $56 \%$ afirmaram saber utilizar corretamente o DEA ${ }^{17}$.

Em muitas situações de emergência, a ausência de conhecimento por parte da população e até mesmo dos profissionais de saúde, pode acarretar inúmeros problemas, como a manipulação incorreta da vítima e solicitação tardia do serviço de emergência ${ }^{18}$.

No que se refere aos primeiros socorros, também houve déficit de conhecimento, com baixas taxas de acertos em ambos os grupos. Pesquisa no Sul do Brasil também identificou que ACS possuem conhecimentos incompletos, comprometendo o socorro à vítima 5 .

Em ambos os grupos apresentaram autoconfiança baixa para intervir em situações de emergências cardíacas, neurológicas e respiratórias. Aprimorar a autoconfiança é um artifício chave na tomada de decisões corretas em situações de emergência, pois a baixa autoconfiança pode se traduzir em atrasos no socorro, maiores níveis de ansiedade e maior probabilidade de $\operatorname{erros}^{19}$.

É importante, portanto, capacitar e empoderar os ACS no atendimento a pequenas urgências e situações de primeiros socorros. Tais capacitações devem ser adequadas à realidade sociodemográfica e de saúde de cada território. Vale ressaltar que os ACS são naturalmente procurados para orientações, sendo estes também multiplicadores de conhecimento ${ }^{6}$. 
Desse modo, o processo continuado de treinamento, com múltiplas artifícios didáticos devem ser implementados para aumentar o conhecimento e também as habilidades dos profissionais, para que os ACS tenham autoconfiança para intervir.

A educação em primeiros socorros também se torna indispensável para profissionais que atuam no território, visto que, é visível a ausência de conhecimento diante dos casos que necessitam dessa atuação rápida ${ }^{20}$.

Assim, o ensino de primeiros socorros para ACS deve ser amplamente difundido e democratizado, por meio de cursos teórico-práticos, como modo de prevenir a morbimortalidade da população em relação aos fatores e consequências relacionadas com a inadequada manipulação da vítima e controle de situações relacionadas às causas externas ${ }^{4}$.

\section{Conclusão}

Os achados da pesquisa apontam déficit de conhecimento dos ACS para atuar frente a PCR e em situações de primeiros socorros, associado à baixa autoconfiança para intervir em situações de emergências cardíacas, respiratórias e neurológicas.

Há necessidade da qualificação dos ACS com implementação de cursos de capacitação para assegurar novos conhecimentos, além de garantir o atendimento ágil e efetivo à frente das diversas situações de emergência e/ou primeiros socorros que possam vim a acontecer na comunidade.

Destaca-se como limitação a não realização da avaliação das habilidades práticas dos ACS para atuar diante da PCR. Dessa forma, sugere-se a realização de novos estudos que programem treinamentos com o protocolo que avaliem conhecimento e prática desses profissionais.

Conflito de interesses: Os autores declaram que não há nenhum conflito de interesses.

Financiamento: Não houve financiamento para esse estudo.

\section{Referências}

1. Morosini MV, Fonseca AF. Os agentes comunitários na Atenção Primária à Saúde no Brasil: inventário de conquistas e desafios. Saúde debate 2018;42(1): 261-274.

https://doi.org/10.1590/0103-11042018s117

2. Ramos MN, Morosini MV, Fonseca AF. Processo de Trabalho dos Técnicos em Saúde na perspectiva dos saberes, práticas e competências [relatório de Pesquisa]. Rio de Janeiro: OPAS; Fiocruz; 2017.

3. Chehuen Neto JA, Brum IV, Pereira DR, Santos LG, Moraes SL, Ferreira RE. Conhecimento e Interesse sobre Suporte Básico de Vida entre Leigos. Int J Cardiovasc Sci [Internet]. 2016 [cited 2019 Feb 20]; 29 (6):443-452. Available from:

http://www.onlineijcs.org/sumario/29/pdf/v29n6a04.pdf

4. Farias DC, Celino SDM, Peixoto JBS, Barbosa ML, Costa GMC. Acolhimento e Resolubilidade das Urgências na Estratégia Saúde da Família. Rev bras educ med. 2015;39 (1): 79-87.

https://doi.org/10.1590/1981-52712015v39n1e00472014 
5. Ventorini JAO, Badke MR, Cogo SB, Cosentino SF, Santos VO. Conhecimentos e conduta dos agentes comunitários de saúde frente aos primeiros socorros. Rev Enferm UFSM 2012; 2(2):353-364. https://doi.org/10.5902/217976925232

6. Sousa LBS, Otaviano MDA, Felix TA, Vasconcelos AKB, Feijão DMJ, Oliveira EN. Capacitação de agentes comunitários de saúde em pequenas urgências: compartilhando experiências. Sanare 2014;13 (2): 57-62. Available from:

https://sanare.emnuvens.com.br/sanare/article/view/574

7. American Heart Association (AHA). Guidelines for Cardiopulmonary Resuscitation and Emergency Cardiovascular Care. Destaques da atualização das Diretrizes da AHA 2015 para RCP e ACE. Texas (EUA): American Heart Association; 2015. Available from: https:// eccguidelines.heart.org/wp-content/uploads/2015/10/2015-AHA-Guidelines-HighlightsPortuguese.pdf

8. Martins JCA, Baptista RCN, Coutinho VRD, Mazzo A, Rodrigues MA, Mendes IAC. Selfconfidence for emergency intervention: adaptation and cultural validation of the Selfconfidence Scale in nursing students. Rev Latino-Am Enferm. 2014;22(4):554-61. https://doi.org/10.1590/0104-1169.3128.2451

9. Nogueira LS, Wilson AMMM, Karakhanian ACM, Parreira EV, Machado VMP, Mira VL. Avaliação dos conhecimentos e habilidades em ressuscitação cardiopulmonar assimilados por profissionais da atenção primária em saúde. Sci Med 2018;28(1):1-9.

http://dx.doi.org/10.15448/1980-6108.2018.1.28843

10.Silva KR, Araújo SAST, Almeida WS, Pereira IVDS, Carvalho EAP, Abreu MNS. Parada cardiorrespiratória e o suporte básico de vida no ambiente pré-hospitalar: O Saber Acadêmico. Rev Saúde Santa Maria 2017;43(1):53-59. http://dx.doi.org/10.5902/2236583422160

11.Silva AC, Bernardes A, Évora YDM, Dalri MCB, Silva AR, Sampaio CSJC. Development of a virtual learning environment for cardiorespiratory arrest training. Rev Esc Enferm 2016;50(6):990-997. http://dx.doi.org/10.1590/S0080-623420160000700016

12.Kaihula WT, Sawe HR, Runyon MS, Murray BL. Assessment of cardiopulmonary resuscitation knowledge and skills among healthcare providers at an urban tertiary referral hospital in Tanzania. BMC Health Serv Res 2018;18 (1): 935-946. http://dx.doi.org/10.1186/s12913-018-3725-2

13.Kelay MM, Kassa H, Birhanu Z, Sinafikish A. A cross sectional study on knowledge, practice and associated factors towards basic life support among nurses working in amhara region referral hospitals, northwest Ethiopia 2016. Hos Pal Med Int Jnl. 2018; 2(2):123-130.

https://doi.org/10.15406/hpmij.2018.02.00070

14. Moraes TPR, Paiva EF. Enfermeiros da Atenção Primária em suporte básico de vida. Rev Ciênc Méd. 2017;26(1):9-18. https://doi.org/10.24220/2318-0897v26n1a3783

15. Bauer AC, Carvalho DFS, Franco GF, Costa JM, Carvalho DFS, Taha Junior K. Suporte Básico de Vida: Atualização das Diretrizes da American Heart Association 2017. Rev Cient Multid Núcleo do Conhecimento, 2018;4(4):83-98. Available from:

https://www.nucleodoconhecimento.com.br/saude/suporte-basico-de-vida

16.Monsieurs KG, Nolan JP, Bossaert LL, Greiff R, Maconochie IK, Nikolaou NI, et al. European Resuscitation Council Guidelines for Resuscitation 2015 Section 1. Executive summary. Resuscitation. 2015;95(1):1-80. https://doi.org/10.1016/j.resuscitation.2015.07.038

17.Einav S, Wacht O, Kaufman N, Alkalay E. Cardiopulmonary arrest in primary care clinics: more holes than cheese: a survey of the knowledge and attitudes of primary care physicians regarding resuscitation. Isr J Health Policy Res 2017;6:22-29.

https://doi.org/10.1186/s13584-017-0148-1

18.Ferreira MGN, Alves SRP, Souto CGV, Virgínio NA, Júnior JNBS, Santos AF. O leigo em primeiros socorros: uma revisão integrativa. Rev Ciênc saúde Nova esperança 2017;15(3):1-9. https://doi.org/10.17695/issn.2317-7160.v15n3a2017p12-20 
19.Martins JCA, Coutinho VR, Baptista RC, Oliveira LM, Gonçalves RF, Paiva LA, et al. Impact of a simulated practice program in the construction of self-confidence for intervention in emergencies and its association with knowledge and performance. J Nurs Edu and Practice. 2017;7(1):45-50. https://doi.org/10.5430/jnep.v7n1 p45

20.Matos DON, Souza RS, Alves SM. Inclusão da disciplina de primeiros socorros para alunos do ensino básico. Rev Interdv. 2016;9(3) 168-178. 